Acest articol se citează:

Spînu, R.-M., (2017/2018). Intervenții în managementul greutății. Studia Doctoralia. Psychology and Educational Science, 13-14, 4-21.

\title{
INTERVENȚII ÎN MANAGEMENTUL GREUTĂȚII
}

\author{
Roxana-Mihaela Spînu, Universitatea din București, Facultatea de \\ Psihologie și Științele Educației. \\ Email: spinuroxanamihaela@gmail.com
}

\begin{abstract}
Given the high rate of obesity around the world and its treatment costs, any potential intervention should be highly cost-effective. The article aims to provide an overview of the different types of interventions in weight management, their specific advantages and disadvantages, as well as their effectiveness. Moreover, it presents behavioral, cognitivebehavioral interventions and eHealth interventions in weight loss programs. The latter represents an innovation in the field, given its apparent utility and benefits, although further research is still needed in order to gain a deeper understanding of the topic.
\end{abstract}

Keywords: obesity, overweight, health, interventions, behavioral interventions, cognitive interventions, eHealth interventions, tehnology.

\section{Introducere}

După Cooper și Fairburn (2001), există trei abordări principale pentru tratarea obezității, abordări testate prin metode științifice și adoptate ca fiind de încredere. Acestea sunt operațiile chirurghicale (operații bariatrice), farmacoterapia și intervențiile comportamentale. Operațiile bariatrice sunt recomandate persoanelor care suferă de obezitate extremă, având un indice IMC mai mare de $40 \mathrm{de} \mathrm{kg} / \mathrm{m} 2$. De obicei, rezultatele acestor intervenții pot fi observate în decurs de 6-12 luni și sunt, în general, rezultate pe termen lung. Farmacoterapia presupune tratamentul $\mathrm{cu}$ medicamente, având ca rezultat pierderi de 
5\%-10\% din greutatea inițială în decurs de 6 luni. Rezultatele sunt modeste, iar cei mai mulți oameni rămân supraponderali. În cazul în care tratamentul este oprit, greutatea inițială se redobândește aproape complet. Așadar, tratamentul medicamentos trebuie continuat permanent, fapt ce are consecințe negative asupra stării de sănătate. Intervențiile comportamentale produc pierderi de până la $10 \%$ din greutatea inițială, însă aproximativ $40 \%$ dintre pacienți își recapătă kilogramele. $\mathrm{Cu}$ toate acestea, intervențiile comportamentale produc o scădere în greutate semnificativă din punct de vedere clinic (Coons et al., 2012) și au avantajul de a fi mai puțin costisitoare și de a avea mai puține efecte negative decât cele farmaceutice sau chirurgicale (Arem \& Irwin, 2011). Așa cum arată și Wing (2002), în urma unei intervenții comportamentale, pacienții pierd în jur de $0,5 \mathrm{~kg}$ sau $1 \mathrm{~kg}$ pe săptămână și aproximativ $8,5 \mathrm{~kg}-9 \mathrm{~kg}$ pe toată durata tratamentului.

Pe lângă aceste trei abordări, Manzoni și colaboratorii (2011) menționează și intervențiile care au ca obiectiv strict modificări ale dietei sau modificări în activitatea fizică. Toate aceste cinci intervenții pentru managementul greutăţii menționate mai sus prezintă numeroase dificultăți în ceea ce privește disponibilitatea, costurile, aderența la tratament și eficacitatea pe termen lung (Manzoni et al., 2011, apud Levy et al., 2007).

\section{Intervenții comportamentale}

Intervențiile comportamentale pentru managementul greutății au început să fie studiate în urmă cu 30 de ani (Wadden et al., 2004). Acestea au ca scop reducerea aportului energetic, pe de o parte, și creșterea consumului de energie, pe de altă parte (Coons et al., 2012). Ele vizează modificări în ceea ce privește dieta, activitatea fizică și comportamentul și folosesc ca strategii auto-monitorizarea, stabilirea obiectivelor, consolidarea rezultatelor și controlul mediului. De obicei, tratamentul urmează o structură precisă și durează între 4 și 6 luni, cu întâlniri săptămânale (Wadden \& Butryn, 2003). Principiul de bază constă în faptul că diferitele comportamente învățate ce țin de o dietă și obiceiuri nesănătoase, mâncatul excesiv sau un stil de viață sedentar pot fi modificate și restructurate pentru a contribui la reducerea greutății (Jeffery et al., 2000). 
Multiplele studii realizate asupra intervențiilor comportamentale au arătat eficiența lor în managementul greutății. Pentru a menține rezultatele intervențiilor o perioadă lungă de timp, este nevoie de modificări comportamentale care se concretizează în stabilirea unor obiceiuri sănătoase în ceea ce privește dieta și exercițiile fizice. (Manzoni et al., 2011). Validitatea clinică a acestor intervenții a fost bine documentată și s-au dovedit a fi intervenții de încredere, independente de vârsta, sexul, etnia sau clasa economică din care fac parte indivizii. Pe lângă intervențiile chirurgicale, terapiile comportamentale sunt cele mai studiate și robuste metode prin care se pot obține rezultate semnificative în managementul greutății (Wadden et al., 2004).

În articolul său publicat în 2000, Liao subliniază faptul că intervențiile propriu-zise ar trebui precedate de o fază de început în cadrul căreia să fie evaluați atât factorii fizici, de sănătate, interpersonali și intrapersonali, cât și factorii contextuali, pentru a putea realiza o interpretare multi-factorială a problemei. Acest proces de evaluarea se poate întinde pe parcursul mai multor ședințe, fiind incluse și evaluări psihometrice. Chiar dacă acest lucru poate părea dificil, Liao susține faptul că o înțelegere profundă a acestor factori poate fi extrem de valoroasă în procesul terapeutic.

Conform lui Levy, Finch, Crowell, Talley și Jeffery (2007), intervențiile comportamentale ar trebui să includă următoarele componente: auto-monitorizarea, stabilirea obiectivelor, controlul stimulilor, strategiile cognitive, suportul social și reîntărirea. (1) În ceea ce privește auto-monitorizarea, scopul ei este acela de a determina indivizii să fie conștienți de propria alimentație și propriul stil de viață. Înregistrările comportamentelor sunt folosite pentru a dicerne patternuri comportamentale și pentru a identifica anumiţi stimuli din mediu care pot contribui la supraalimentare sau inactivitate fizică. De exemplu, în urma unui astfel de proces, o persoană își poate da seama că sare peste masa de la prânz, ajungând să mănânce foarte mult după aceea și să acumuleze astfel kilograme. În acest caz, ar putea fi benefic pentru aceasta dacă ar adopta diferite strategii pentru a nu mai sări peste masa de prânz (de exemplu, își poate pregăti prânzul de acasă sau își poate stabili programul zilei în așa manieră încât să își rezerve o oră pentru aceasta). Auto-monitorizarea poate fi folosită ca un instrument pentru 
conștientizarea numărului de calorii pe care organismul unei persoane le primește zilnic și este foarte importantă pentru evaluarea progresului pacientului, precum și pentru internalizarea schimbărilor comportamentale (Levy et al., 2007, apud Shelton \& Levy, 1981).

(2) Stabilirea obiectivelor se face în concordanță cu cele trei componente ale modelului $\mathrm{ABC}$ cognitiv și trebuie să fie exprimate în unități relevante pentru managementul greutății; de exemplu, 1000-2000 kcal/zi (Jeffery, Wing \& Sherwood, 2003). Obiectivele trebuie să fie realiste, dar provocatoare și este important să se stabilească termene limite pentru îndeplinirea lor (Fabricatore, 2007).

(3) Pentru un cât mai bun controlul al mediului (stimulilor), atenția persoanelor trebuie să fie îndreptată spre modificarea comportamentelor anterioare care au dus la supraalimentare și inactivitate fizică. De exemplu, nu tot timpul oamenii mănâncă din cauza senzației de foame; sunt destul de multe situațiile în care aceștia recurg la mâncare din cauza unor tulburări emoționale, a stresului sau a plictiselii. În cazul persoanelor care au tendința de a mânca atunci când sunt stresate, tehnicile de relaxare reprezintă o alternativă bună (Fabricatore, 2007). În aceeași ordine de idei, oamenii ar trebui încurajați să manipuleze mediul în așa manieră încât să înmulțească indicii din jurul lor care îi conduc spre adoptarea unor comportamente sănătoase (cum ar fi punerea unei farfurii cu fructe pe birou) și să evite indicii care îi conduc spre comportamente nesănătoase, cum ar fi dulapul cu dulciuri. (Levy et al., 2007, apud Blundell et al., 1996).

(4) Un alt factor care duce la supraalimentare este gândirea dezadaptativă. Gânduri precum „Am avut o zi grea, deci merit un desert" sau "Știu că nu sunt capabil să duc această dietă la final" sunt predictori puternici ai supraalimentării și inactivității fizice. Astfel, intervențiile comportamentale folosesc strategii cognitive pentru evita aceste situații. Pacienții ar putea fi rugați să își monitorizeze aceste gânduri și emoții înainte și după masă, urmând ca fiecare gând negativ să fie evaluat și contracarat de gânduri adaptative, cum ar fi „Am avut o zi grea, merit o recompensă, deci voi face o baie caldă" (Levy et al., 2007, apud Blundell et al., 1996).

(5) Suportul social este un factor important în tratarea obezităţii. Studiile au arătat faptul că persoanele care se percep susținute de cei din 
jur vor avea mai mult succes în procesul de pierdere a excesului de greutate (Wolfe, 2004). Din această perspectivă, intervențiile care folosesc ședinte de grup în locul ședințelor individuale prezintă rezultate mai bune deoarece grupul poate stimula motivația și înjurajează implicarea participanților în adoptarea unor strategii optime pentru pierderea greutății (Khaylis et al., 2010, apud Renijilian, Raab \& Adams, 2009).

(6) De asemenea, întărirea comportamentelor influențează rezultatele intervenției, iar pacienții trebuie încurajați să își recompenseze și cele mai mici schimbări de comportament. Trebuie însă conștientizat faptul că sunt permise doar recompensele care nu intră în contradicție cu scopul intervenției. Personale nu își pot oferi deserturi ca recompense, dar pot participa la diverse activități sociale, își pot oferi recompense materiale sau își pot petrece timpul făcând ceva care le aduce satisfacție (Levy et al., 2007, apud Blundell et al., 1996).

National Institute of Health [NIH] (2012) recomandă ca programele care vizează tratamentul persoanelor obeze să includă trei aspecte: modificări ale dietei, modificări ale activității fizice și modificări ale comportamentului. Modificările în ceea ce privește dieta se referă la încurajarea oamenilor în a consuma între 1200 și 1800 de kilocalorii pe zi, nu mai mult de 20\%-30\% de calorii provenite din grăsimi. Modificări în activitatea fizică includ creșteri progresive ale efortului fizic, de la 30 sau 40 de minute pe zi, până la 150 de minute de activitate fizică. Schimbările comportamentale includ adoptarea unei diete sănătoase, creșterea activității fizice și modificarea factorilor de mediu care favorizează comportamente nesănătoase (Van Dorsten \& Lindley, 2011). Aceste schimbări comportamentale constau într-o serie de strategii prin care se urmărește susținerea și întărirea unor comportamente dezirabile și reducerea frecvenței unor comportamente indezirabile (Van Dorsten \& Lindley, 2011, apuc Milteberger, 1997).

$\mathrm{Cu}$ toate că intervențiile comportamentale sunt foarte eficiente în procesul de pierdere a greutății, acestea prezintă mai multe limite. Sunt costisitoare, consumă mult atât din timpul pacienților, cât și din timpul terapeuților, fiind greu de livrat întregii populații (Coons et al., 2012). Auto-monitorizarea, componentă a intervențiilor comportamentale „ffaţă-în-față” este greoaie și predispusă la inexactități. Este un proces 
destul de dificil pentru oameni să își monitorizeze dieta folosind metoda creion-hârtie și să facă asta cu consecvență (Stone, Shiffman, Schwartz, Broderick \& Hufforz, 2003). În aceeași ordine de idei, există o tendință a oamenilor de a subevalua aportul de calorii pe care organismul îl primește și de a supraestima activitatea fizică și deci, consumul de calorii (Prince et al., 2008). Consilierea, o altă componentă a intervențiilor comportamentale reprezintă un mediator important în procesul de pierdere a greutății (Perri et al., 2014), însă furnizarea acestui serviciu în cadrul intervențiilor tradiționale de tip față-în-față este destul de costisitor (Raaijmakers et al., 2015).

Pe lângă aceste limite, intervențiilor comportamentale prezintă dezavantajul de a se orienta mult pe modificarea comportamentului, în timp ce acordă foarte puțină atenție aspectelor cognitive, cum ar fi gândurile, credințele, emoțiile, auto-eficacitatea asociată procesului de pierdere a greutății (Fabricatore, 2007). Acest aspect face ca eficiența intervențiilor comportamentale să fie limitată deoarece cognițiile iraționale, precum „Nu voi face niciun rău dacă astăzi nu îmi voi respecta dieta", vor ajunge să dirijeze comportamentul (Ioana Podina, comunicare personală). Așadar, este important ca, în tratamentul obezității, să se intervină în egală măsură atât asupra comportamentului, cât și asupra cognițiilor care îl dirijează. Acest aspect este susținut și de Raaijmakers și colaboratorii (2015) care sugerează faptul că intervențiile utilizate în managementul greutății ar trebui să se bazeze pe teoriile și formele de terapie robuste și de încredere, ca terapia cognitivcomportamentală.

\section{Intervenții cognitiv-comportamentale}

Terapia cognitiv comportamentală (CBT) a fost fondată de Albert și Ellis și este cea mai studiată formă de psihoterapie. Aceasta se referă la o clasă de intervenții care au la bază premisa conform căreia tulburările mentale și distresul psihologic sunt cauzate de factori de natură cognitivă (scheme și convingeri despre lume, eu sau viitor care dau naștere unor gânduri automate în situații specifice). Cognițiile dezadaptative contribuie la menținerea distresului emoțional și a problemelor comportamentale. În concordanță cu modelul medical psihiatric, obiectivul principat al terapiei cognitiv-comportamentale este 
reducerea simptomului, îmbunătățirea funcționării și diminuarea și atenuarea tulburării. În vederea atingerii acestor obiective, pacientul devine un participant activ în procesul colaborativ dintre acesta și terapeut, proces în care se urmărește evaluarea cognițiilor și comportamentelor dezadaptative și înlocuirea acestora, atunci când este cazul, cu cogniții adaptative (Hoffman, Asnaani, Vonk, Sawyer \& Fang, 2012).

Așadar, acest tip de terapie le oferă pacienților oportunitatea de a identifica pattern-uri cognitive și de comportament care favorizează sau, dimpotrivă, au efecte negative asupra procesului de pierdere a greutății. În cazul tratării obezității, CBT prezintă marele avantaj de a oferi pacienților mijloace de manipulare a cognițiilor asociate schimbărilor comportamentale (și în special în cazul urmării unei diete), redobândirii greutății, eșecurilor repetate de-a lungul intervenției și așa mai departe (Stahre, Tarnell, Hakanson \& Hallstrom, 2007).

Eficacitatea intervențiilor CBT în managementul greutății a fost studiată de mulți cercetători, ajungându-se la următoarele rezultate. Shaw și colaboratorii (2005) au concluzionat faptul că intervențiile cognitiv-comportamentale, împreună cu dieta și activitățile fizice duc la rezultate mai bune din punct de vedere clinic decât intervențiile care se concentrează doar pe dietă și activitate fizică. Astfel, în cazul primelor intervenții a fost înregistrată o medie de $7,3 \mathrm{~kg}$ mai puțin, iar în cazul celui de-al doilea tip de intervenție, au fost întregistrate pierderi de doar 2,4 kg. Painot și colaboratorii (2001) au selectat un eșantion de 70 de participanți și au investigat eficiența intervențiilor CBT, a dietei și a activității fizice pe de o parte, și doar eficiența intervențiilor CBT, pe de altă parte. Rezultatele au arătat pierderi de $1,9 \mathrm{~kg}$ pentru tratamentul combinat și 0,5 kg pentru tratamentul bazat doar pe intervenții CBT. În mod siminar, Sbrocco și colaboratorii (1999) au dorit să observe diferențele în eficiență în cazul intervențiilor cognitiv-comportamentale, comparativ cu intervențiile comportamentale. Rezultatele au relevat faptul că, în cazul primelor intervenții, media kilogramelor pierdute era de $10 \mathrm{~kg}$, pe când în cazul celei de-a doua intervenții, s-au înregistrat pierderi de doar $4,5 \mathrm{~kg}$.

În ceea ce privește tulburările alimentare, terapia cognitivcomportamentală s-a dovedit a fi eficientă atât în tratarea bulimiei 
(Hofmann et al., 2012), cât și în tratarea episoadelor de "binge eating" (Reas \& Grilo, 2008). Reas și Grilo au demonstrat faptul că terapia cognitiv-comportamentală este mai eficientă în tratarea episoadelor de binge eating decât farmacoterapia, în timp ce Hay, Bacalthuk, Stefano și Kashyap (2009) au concluzionat faptul că acest tip de terapie este mai eficient decât terapia interpersonală, hipnoza, psihoterapia suportivă, terapia comportamentală si auto-monitorizarea în tratarea bulimiei.

În ceea ce privește obezitatea, terapiile cognitiv-comportamentale pot duce la pierderi de până la $10 \%$ din totalul greutății inițiale, comparativ cu tratamentele tradiționale care ating un maximum de $5 \%$ pierderi din greutatea inițială. $\mathrm{Cu}$ toate acestea, rezultatele pe termen lung ale acestor terapii nu sunt atât de promițătoare. Participanții tind să își mențină greutatea dobândită în proporție de 60\%-70\% timp de un an, dar în următorii cinci ani, majoritatea participanților revin la greutatea iniţială în proporție de $100 \%$ (Liao, 2000). Așadar, strategiile cognitivcomportamentale prezintă rezultate foarte bune pe termen scurt, dar nu sunt la fel de efciente pe termen lung.

În ciuda dezvoltării tratamentelor comportamentale și cognitivcomportamentale, prevalența obezității și a afecțiunilor asociate acesteia sunt într-o continuă creștere (Raaijmakers et al., 2015), ceea ce determină orientarea cercetătorilor către metode inovative de intervenție în cadrul managementului greutății, metode care să aibă efect atât pe termen scurt, cât și pe termen lung. Intervențiile față-în-față sunt destul de inconveniente din punct de vedere al balanței dintre resursele folosite în implementarea lor și rezultatele obținute (Khaylis et al., 2010). În plus, datorită numărului tot mai mare de persoane care suferă de obezitate (300 de milioane de persoane obeze și 2 miliarde de persoane supraponderale (Collingwood, 2007)), intervențiile standard, atât individuale, cât și de grup nu sunt suficiente pentru a acoperi toată masa de oameni care ar avea nevoie de intervenții în acest sens. Astfel, dezvoltarea unor programe online este o soluție optimă care ar putea veni în întâmpinarea acestor probleme (Wing et al., 2001). În acest sens, intervențiile tehnologizate care folosesc strategii tradiționale pentru modificarea comportamentului în vederea pierderii greutății încep să devină din ce în mai promițătoare (Khaylis et al., 2010). 
În prezent, sunt folosite 3 mari modalități de livrare a serviciilor de CBT prin intermediul tehnologiei (eCBT): programe livrate cu ajutorul computerului și al internetului, programe de realitate virtuală și aplicații prin intermediul smartphone-ului (Podina, Moase, David, Szwntagotai \& Dobrean, 2015). Tot Podina (2015) menționează avantajele intervențiilor eCBT: acestea prezintă un control crescut atât pentru pacient, cât și pentru terapeut, sunt ușor de accesat, sunt portabile și asigură confidențialitate, reproductibilitate și siguranță. De asemenea, sunt extrem de valorizate de adolescenți și copii, dar și de adulți. Un alt avantaj important al intervențiilor eCBT face referire la aspectul economic, aceste intervenții salvând în jur de 540\$-630\$ pe client, comparativ cu intervențiile standard cognitiv-comportamentale.

Intervenţii tehnologizate în managementul greutății (eng. eHealth interventions). Avantajele utilizării internetului și a telefoanelor mobile

Conform CTIA Wireless Association (2009), în Statele Unite ale Americii, mai mult de $87 \%$ din populație posedă un telefon mobil. În 2014, aproximativ 40\% din populația lumii și 78\% în țările dezvoltate folosea internetul, iar aproximativ 32\% din oamenii din întreaga lume și $84 \%$ din țările dezvoltate dețineau un telefon mobil (Hutchesson et al., 2015). În ceea ce privește utilizarea telefoanelor mobile, studiile arată că, între 2005 și 2010, numărul persoanelor care dețineau un telefon mobil a crescut de la 2 miliarde la mai mult de 5 miliarde în întreaga lume (Stephens \& Allen, 2013).

Numărul persoanelor care dețin un smartphone este, de asemenea, în creștere, mulți cercetători susținând faptul că, în curând, telefoanele mobile tradiționale vor fi înlocuite de aceste dispozitive noi. Marele avantaj al smartphone-urilor îl reprezintă faptul că sunt considerate a fi "calculatoare portabile" și pot îndeplini aproape toate funcțiile pe care calculatoarele obișnuite le îndeplinesc, oferind cercetătorilor vaste oportunități pentru crearea de aplicații prin care să promoveze tehnici de menținere a stării de sănătate, de prevenție a diferitelor afecțiuni sau de intervenție în cazul persoanelor care suferă de anumite tulburări (Stephens \& Allen, 2013). De asemenea, dispozitivele portabile au avantajul de a putea fi folosite și în afara 
sistemului medical sau al locuinței oamenilor, astfel fiind foarte ușor de integrat în viața de zi cu zi, mai ales în cazul în care programul de lucru al acestora este foarte încărcat (Bacigalupo et al., 2013).

În ciuda acestor avantaje, cât și a faptului că extrem mulți oameni au acces la tehnologie și telefoane mobile, chiar și smartphone-uri, folosirea acestora de către sistemul de sănătate cu în scopul tratării diferitelor afecțiuni este încă la început (Krishna et al., 2009). Shaw \& Bosworth (2012) afirmă faptul că destul de multe programe care vizează managementul greutății au început să adopte mesajele text ca un mijloc de intervenție. O scurtă căutare pe internet relevă existența a numeroase metode tehnologizate de intervenție, inclusiv existența unor aplicații pentru smartphone-uri, însă numărul acestora este încă mic comparativ cu populația țintă.

Intervenţiile tehnologizate sau intervențiile eHealth pentru managementul greutății presupun aplicarea tehnologiilor informației și comunicațiilor (eng. ICT) peste toate aspectele ce țin de asistența medicală, de la etapa de diagnostic până la etapa de menținere a greutății obținute (Catwell \& Sheikh, 2009, apud Siber, 2003). Acestea sunt intervenții structurate ce încorporează principiile și componentele terapiei comportamentale și cognitiv-comportamentale prin comutarea în mediul virtual a acestora (Khaylis et al., 2010). Cercetările arată că interacțiunea online dintre pacient și terapeut este la fel de eficientă ca interacțiunea ce are loc față-în-față, în condițiile unei intervenții tradiționale (Khaylis et al., 2010, apud Hunter et al., 2008). În marea majoritate a cazurilor, acest tip de intervenții sunt livrate prin internet, tablete, e-mail, telefoane mobile sau smartphone-uri, jocuri sau aşanumiții „asistenți personali digitali” (eng. personal digital assisstent [PDA]) (Hutchesson et al., 2015).

Khaylis și colaboratorii (2010) afirmă faptul că găsirea unor modalități de livrare a componentelor terapiilor tradiționale în mediul online (prin intermediul internetului sau al telefonului mobil) ar facilita considerabil atât accesul la informații, cât și procesul de automonitorizare. Un review realizat de Krishna și colaboratorii (2009) arată că intervențiile tehnologizate care au folosit telefoanele mobile ca metodă principală de livrare au avut rezultate mai bune comparativ cu metodele tradiționale de management al greutății. Mesajele text s-au 
dovedit a fi foarte folositoare în sporirea numărului de întâlniri cu terapeutul și în menținerea contactului cu acesta pentru o lungă perioadă de timp. Meta-analiza realizată de Raaijmakers și colaboratorii (2015) concluzionează faptul că intervențiile tehnologizate de management al greutății care sunt livrate cu ajutorul telefonului mobil prezintă rezultate semnificative pe termen scurt, și rezultate moderate pe termen lung. În ceea ce privește intervențiile livrate prin intermediul unui website, în ultimii zece ani, acestea au fost testate și dezvoltate pentru o varientate de tulburări, inclusiv pentru managementul greutății, dovedindu-se eficacitatea lor. Platformele web care sunt accesate de mulți oameni pot fi livrate fără costuri datorită auto-susținerii acestora prin intermediul reclamelor (Wieland et al., 2012).

Așa cum a fost menționat și anterior, oamenii întâmpină dificultăți frecvente atunci când este vorba de auto-monitorizarea comportamentelor prin metoda creion-hârtie, iar mulți dintre ei tind să subestimeze aportul energetic zilnic, în timp ce supraestimează consumul de calorii. În acest sens, intervențiile tehnologizate prezintă avantajul de a fi mult mai uşor de utilizat, iar faptul că automonitorizarea se face online, în timp real, crește obiectivitatea procesului (Coons et al., 2012). Studiile au arătat faptul că auto-monitorizarea tehnologizată duce la rezultate mult mai bune: pierderi în greutate mai mari și îmbunătățiri ale activității fizice (Khaylis et al., 2010, apud Tate el al., 2011). Motivul pentru care auto-monitorizarea tehnologizată este mai eficientă decât cea tradițională se datorează faptului că dispozitivele purtabile sunt mai ușor de folosit, ceea ce face ca procesul de monitorizare să fie continuu. Un alt motiv îl reprezintă faptul că transmiterea informațiilor în cadrul monitorizării, prin intermediul tehnologiei, către un terapeut îl face pe om să fie mult mai responsabil pentru dietă și atingerea obiectivelor personale decât păstrarea informațiilor pentru sine. $\mathrm{Cu}$ alte cuvinte, auto-monitorizarea tehnologizată are efecte pozitive asupra motivației (Tate, Jackvony \& Wing, 2006).

Aderența în cadrul intervențiilor tehnologizate, conceptualizată prin acțiuni ca numărul de accesări ale platformelor, eficiența automonitorizării dietei, numărul de răspunsuri la mesajele text (în cazul intervențiilor care folosesc ca metodă de livrare telefoanele mobile) este 
mult mai bună decât în cazul intervențiilor tradiționale. Acest aspect este verificat și de Wharton, Johnston, Cunningham șii Sterner în studiul lor realizat în 2014; participanții cărora li s-a livrat o intervenție cu ajutorul unei aplicații pentru smartphone au fost mult mai riguroși în urmarea tratamentului decât cei care au folosit metoda tradițională "creion-hârtie".

Un alt avantaj al intervențiilor computerizate constă în suportul social oferit prin mesaje și forumuri. Cu cât percepția acestui suport social este mai mare, cu atât frecvența conectărilor la platformă va fi mai mare, ceea ce va duce la rezultate mai bune în ceea ce privește scăderea în greutate. Studiile au arătat că utilizarea forumurilor de pe platforme este asociată cu o scădere semnificativă de greutate, rezultatele menținându-se pe termen lung (Gold, Burke, Pintauro, Buzzell, harveyBerino, 2007). Intervențiile tehnologizate care nu includ forumuri sau suport social în general prezintă rate mai scăzute de utilizare și rezultate nesemnificative statistic (McConnon et al., 2007). Cercetătorii sugerează că o comunicare online cu terapeutul este la fel de eficientă ca o comunicare față-în-față, ceea ce are implicații directe asupra costurilor. Mai mult decât atât, există posibilitatea transpunerii tehnicilor folosite de intervențiile tradiționale în intervenții tehnologizate. Astfel, participanții își pot monitoriza dieta în mediul online, iar feedback-urile, încurajările și recomandările primite de la terapeut vor duce la scăderi semnificative în greutate (Khaylis et al., 2010).

Intervențiile tehnologizate sunt ușor de livrat și implementat (Khaylis et al., 2010), putând, astfel, acoperi o masă mai mare de oameni care au nevoie de intervenții pentru managementul greutății (Arem \& Irwin, 2011). Tot Khaylis și colaboratorii (2010) evidențiază faptul că intervențiile tehnologizate pot fi foarte ușor încorporate în ritmul de viață alert și programul încărcat al oamenilor, reducând, așadar, rezistența pe care unii oameni o manifestă în angajarea într-o astfel de intervenție. De asemenea, intervențiile tehnologizate oferă oamenilor un oarecare sentiment de control care este esențial în adoptarea modificărilor comportamentale pe termen lung și scurt. În aceeași ordine de idei, Stephen \& Allen (2013), citându-l pe Haala și colaboratorii (2009), susțin faptul că intervențiile eHealth oferă acel grad de flexibilitate necesar pentru ca oamenii să le poată integra în stilul lor de viață. Tot 
Stephen și Allen, în urma studiului realizat de ei, ajung la concluzia că aspectele tehnologizate adăugate intervențiilor tradiționale îmbunătățesc rezultatele în mod considerabil.

Intervențiile tehnologizate oferă posibilitatea ca pacienții să rămână anonimi și adaptează informațiile și metodele de intervenție la specificul fiecăruia. De asemenea, oamenii se bucură de oportunitatea de a primi sfaturi de la experți în domeniul sănătătii (Raaijmakers et al., 2015), aceștia având la dispoziție oportunități de intervenție inovative și interactive care cresc interesul oamenilor (Manzoni et al., 2011). În plus, contactul dintre pacient și terapeut poate fi menținut pe o perioadă lungă de timp, ceea ce are o influență pozitivă asupra menținerii greutății dobândite (Weinstein, 2006).

Un alt avantaj face referire la aspectul economic. Wieland și colaboratorii (2012) susțin faptul că intervențiile tehnologizate sunt mult mai avantajoase din punct de vedere economic, unele fiind chiar gratis pentru pacienți. Acest lucru este posibil datorită reclamelor din cadrul aplicațiilor pentru smartphone care „suportă" costurile aferente intervențiilor pentru tratarea obezității.

Datorită acestui mare impact asupra sistemului de sănătate, o cât mai bună înțelegere a intervențiilor tehnologizate este critică pentru formularea celor mai bune strategii în tratamentul supraponderalității și obezității. (Wieland et la., 2012). Este absolut necesară realizarea mai multor cercetări în acest domeniu pentru a întelege mai bine conceptul de eHealth și tehnologia informației și comunicației. Catwell și Sheikh (2009) recomandă realizarea de evaluări care să vizeze toate aspectele intervențiilor tehnologizate până în momentul în care acest tip de intervenție va putea asigura eficacitatea, eficiența economică și siguranța pe termen scurt, mediu și lung.

\section{Variabile care influențează intervențiile în managementul greutăţii}

Studiile au relevat existenţa unor categorii de moderatori care favorizează relația dintre intervențiile comportamentale sau cognitivcomportamentale, fie ele tehnologizate sau tradiționale, și rezultatele exprimate în termenii greutății pierdute. Centrul de cercetare Foresight din Marea Britanie a identificat mai mult de o sută de variabile care afectează direct sau indirect rezultatele intervențiilor (Dobbs et al., 2014). 
Review-ul sistematic realizat de Coons și colaboratorii (2012) a scos în evidență faptul că auto-monitorizarea și activitatea fizică au cel mai mare succes în ceea ce privește scăderea în greutate și menținerea acesteia. Review-ul realizat de Raaijmakers și colaboratorii (2015) a arătat faptul că feedback-ul terapeutului și motivația pacientului au un impact pozitiv asupra procesului de pierdere a greutății. Suportul social este, de asemenea, important în tratamentul obezității (Greaves et al., 2011). La fel, mai multe studii au arătat faptul că intervențiile personalizate sunt mai eficiente decât cele standard, aplicate întregului grup (Raaijmakers et al., 2015; Kreuter \& Wray, 2003).

Un review asupra eficacității intervențiilor tehnologizate în managementul greutății realizat de Khaylis și colaboratorii (2010) a identificat cinci componente cheie care duc la succesul unor astfel de intervenții: auto-monitorizarea, feedback-ul terapeutului și buna comunicare $\mathrm{cu}$ acesta, suportul social, folosirea unor metode structurate (de exemplu, terapia cognitiv-comportamentală) și a unor intervenții individualizate pentru fiecare persoană în parte.

\section{Bibliografie}

Arem, H., \& Irwin, M. (2011). A review of web-based weight loss interventions in adults. Obesity Reviews, 12(5), e236-e243.

Bacigalupo, R., Cudd, P., Littlewood, C., Bissell, P., Hawley, M. S., \& Buckley Woods, H. (2013). Interventions employing mobile technology for overweight and obesity: an early systematic review of randomized controlled trials.Obesity reviews, 14(4), 279-291.

Catwell, L., \& Sheikh, A. (2009). Evaluating eHealth interventions: the need for continuous systemic evaluation. PLoS Med, 6(8), e1000126.

Collingwood, J. (2007). Obesity and mental health [Psych Central]. Retrieved from http://psychcentral.com/lib/obesity-and-mentalhealth/

Coons, M. J., DeMott, A., Buscemi, J., Duncan, J. M., Pellegrini, C. A., Steglitz, J., ... \& Spring, B. (2012). Technology interventions to curb obesity: a systematic review of the current literature. Current cardiovascular risk reports, 6(2), 120-134. 
Cooper, Z., \& Fairburn, C. G. (2001). A new cognitive behavioural approach to the treatment of obesity. Behaviour research and therapy, 39(5), 499-511.

CTIA Wireless Association. (2009). CTIA Semi-Annual Wireless Industry Survey. Washington, DC, USA.

Dobbs, R., Sawers, C., Thompson, F., Manyika, J., Woetzel, J. R., Child, P., ... \& Spatharou, A. (2014). Overcoming obesity: An initial economic analysis. McKinsey Global Institute.

Fabricatore, A. N. (2007). Behavior therapy and cognitive-behavioral therapy of obesity: is there a difference?. Journal of the American Dietetic Association,107(1), 92-99.

Gold, B. C., Burke, S., Pintauro, S., Buzzell, P., \& Harvey-Berino, J. (2007). Weight loss on the web: A pilot study comparing a structured behavioral intervention to a commercial program. Obesity, 15(1), 155-155.

Greaves, C. J., Sheppard, K. E., Abraham, C., Hardeman, W., Roden, M., Evans, P. H., \& Schwarz, P. (2011). Systematic review of reviews of intervention components associated with increased effectiveness in dietary and physical activity interventions. BMC public health, 11(1), 1.

Hay, P. P., Bacaltchuk, J., Stefano, S., \& Kashyap, P. (2009). Psychological treatments for bulimia nervosa and binging. Cochrane Database Syst Rev, 4, CD000562.

Hofmann, S. G., Asnaani, A., Vonk, I. J., Sawyer, A. T., \& Fang, A. (2012). The efficacy of cognitive behavioral therapy: a review of metaanalyses.Cognitive therapy and research, 36(5), 427-440.

Hutchesson, M. J., Rollo, M. E., Krukowski, R., Ells, L., Harvey, J., Morgan, P. J., .. \& Collins, C. E. (2015). eHealth interventions for the prevention and treatment of overweight and obesity in adults: a systematic review with meta-analysis. Obesity Reviews, 16(5), 376392.

Jeffery, R. W., Epstein, L. H., Wilson, G. T., Drewnowski, A., Stunkard, A. J., \& Wing, R. R. (2000). Long-term maintenance of weight loss: current status. Health psychology, 19(1S), 5.

Jeffery, R. W., Wing, R. R., Sherwood, N. E., \& Tate, D. F. (2003). Physical activity and weight loss: does prescribing higher physical activity 
goals improve outcome?. The American journal of clinical nutrition, 78(4), 684-689.

Khaylis, A., Yiaslas, T., Bergstrom, J., \& Gore-Felton, C. (2010). A review of efficacious technology-based weight-loss interventions: five key components.Telemedicine and e-Health, 16(9), 931-938.

Kreuter, M. W., \& Wray, R. J. (2003). Tailored and targeted health communication: strategies for enhancing information relevance. American Journal of Health Behavior, 27(1), S227-S232.

Krishna, S., Boren, S. A., \& Balas, E. A. (2009). Healthcare via cell phones: a systematic review. Telemedicine and e-Health, 15(3), 231-240.

Levy, R. L., Finch, E. A., Crowell, M. D., Talley, N. J., \& Jeffery, R. W. (2007). Behavioral intervention for the treatment of obesity: strategies and effectiveness data. The American journal of gastroenterology, 102(10), 2314.

Liao, K. L. M. (2000). Cognitive-behavioural approaches and weight management: an overview. The journal of the Royal Society for the Promotion of Health, 120(1), 27-30.

Manzoni, G. M., Pagnini, F., Corti, S., Molinari, E., \& Castelnuovo, G. (2011). Internet-based behavioral interventions for obesity: an updated systematic review. Clinical Practice \& Epidemiology in Mental Health, 7(1).

McConnon, Á., Kirk, S. F., Cockroft, J. E., Harvey, E. L., Greenwood, D. C., Thomas, J. D., ... \& Bojke, L. (2007). The Internet for weight control in an obese sample: results of a randomised controlled trial. BMC health services research, 7(1), 206.

Perri, M. G., Limacher, M. C., Castel-Roberts, K., Daniels, M. J., Durning, P. E., Janicke, D. M., ... \& Martin, A. D. (2014). Comparative effectiveness of three doses of weight-loss counseling: Two-year findings from the rural LITE trial. Obesity, 22(11), 2293-2300.

Prince, S. A., Adamo, K. B., Hamel, M. E., Hardt, J., Gorber, S. C., \& Tremblay, M. (2008). A comparison of direct versus self-report measures for assessing physical activity in adults: a systematic review. International Journal of Behavioral Nutrition and Physical Activity, 5(1), 56. 
Painot, D., Jotterand, S., Kammer, A., Fossati, M., \& Golay, A. (2001). Simultaneous nutritional cognitive-behavioural therapy in obese patients.Patient education and counseling, 42(1), 47-52.

Podina, I. R., Mogoase, C., David, D., Szentagotai, A., \& Dobrean, A. A Meta-Analysis on the Efficacy of Technology Mediated CBT for Anxious Children and Adolescents. Journal of Rational-Emotive $\mathcal{E}$ Cognitive-Behavior Therapy, 1-20.

Raaijmakers, L. C., Pouwels, S., Berghuis, K. A., \& Nienhuijs, S. W. (2015). Technology-based interventions in the treatment of overweight and obesity: A systematic review. Appetite, 95, 138-151.

Reas, D. L., \& Grilo, C. M. (2008). Review and Meta-analysis of Pharmacotherapy for Binge-eating Disorder. Obesity, 16(9), 20242038.

Sbrocco, T., Nedegaard, R. C., Stone, J. M., \& Lewis, E. L. (1999). Behavioral choice treatment promotes continuing weight loss: Preliminary results of a cognitive-behavioral decision-based treatment for obesity. Journal of Consulting and Clinical Psychology, 67(2), 260.

Shaw, R., \& Bosworth, H. (2012). Short message service (SMS) text messaging as an intervention medium for weight loss: a literature review.Health informatics journal, 18(4), 235-250.

Shaw, K., O'Rourke, P., Del Mar, C., \& Kenardy, J. (2005). Psychological interventions for overweight or obesity. Cochrane Database Syst Rev, 2(2).

Stahre, L., Tärnell, B., Håkanson, C. E., \& Hällström, T. (2007). A randomized controlled trial of two weight-reducing short-term group treatment programs for obesity with an 18-month followup. International journal of behavioral medicine, 14(1), 48-55.

Stephens, J., \& Allen, J. (2013). Mobile phone interventions to increase physical activity and reduce weight: a systematic review. The Journal of cardiovascular nursing, 28(4), 320.

Stone, A. A., Shiffman, S., Schwartz, J. E., Broderick, J. E., \& Hufford, M. R. (2003). Patient compliance with paper and electronic diaries. Controlled clinical trials, 24(2), 182-199.

Tate, D. F., Jackvony, E. H., \& Wing, R. R. (2006). A randomized trial comparing human e-mail counseling, computer-automated 
tailored counseling, and no counseling in an Internet weight loss program. Archives of internal medicine, 166(15), 1620-1625.

Van Dorsten, B., \& Lindley, E. M. (2011). Cognitive and behavioral approaches in the treatment of obesity. Medical Clinics of North America, 95(5), 971-988.

Wadden, T. A., \& Butryn, M. L. (2003). Behavioral treatment of obesity.Endocrinology and Metabolism Clinics, 32(4), 981-1003.

Wadden, T. A., Butryn, M. L., \& Byrne, K. J. (2004). Efficacy of lifestyle modification for long-term weight control. Obesity research, 12(S12), 151S-162S.

Weinstein, P. K. (2006). A review of weight loss programs delivered via the Internet. Journal of Cardiovascular Nursing, 21(4), 251-258.

Wharton, C. M., Johnston, C. S., Cunningham, B. K., \& Sterner, D. (2014). Dietary self-monitoring, but not dietary quality, improves with use of smartphone app technology in an 8-week weight loss trial. Journal of nutrition education and behavior, 46(5), 440-444.

Wieland, L. S., Falzon, L., Sciamanna, C. N., Trudeau, K. J., Brodney, S., Schwartz, J. E., \& Davidson, K. W. (2012). Interactive computerbased interventions for weight loss or weight maintenance in overweight or obese people. Cochrane Database Syst Rev, 8(8).

Wing, R. R. (2002). Behavioral weight control. Handbook of obesity

treatment,2, 301-317.

Wing, R. R., Goldstein, M. G., Acton, K. J., Birch, L. L., Jakicic, J. M., Sallis, J. F., ... \& Surwit, R. S. (2001). Behavioral science research in diabetes lifestyle changes related to obesity, eating behavior, and physical activity.Diabetes care, 24(1), 117-123.

Wolfe, W. A. (2004). A review: Maximizing social support-A neglected strategy for improving weight management with AfricanAmerican women. Ethnicity and Disease, 14(2), 212-218. 